\title{
Food banks and food rescue organisations: Damned if they do; damned if they don't
}

Susan Wason, University of Otago, Aotearoa New Zealand

\begin{abstract}
INTRODUCTION: Food banks, a charitable response to a politically driven crisis in Aotearoa New Zealand, have become institutionalised. They emerged in an ad hoc manner and, since the 1980s, have helped address the emergency food needs of those experiencing food poverty. Food Rescue organisations, a later creation, emerged in an organised and planned manner. They have helped to address the needs of those experiencing food poverty by increasing the quantity, and the amount of perishable food available for distribution.

METHOD: This article draws on academic literature and research of the Dunedin/Ōtepoti newsprint media completed for a thesis in 2017 to provide background about how these organisations came to exist and the socio-political context that supports their existence.
\end{abstract}

FINDINGS: The development of food banks in Dunedin/Ōtepoti reflected the global explanations for their rise; however, with the advent of KiwiHarvest the mechanisms for addressing food poverty are undergoing a paradigm shift.

IMPLICATIONS: These new mechanisms have the potential to be more inclusive of those experiencing food poverty. Choice of food, involvement of recipients in the policy setting and the distribution of food, and fewer criteria are possible innovations. There are also opportunities for this new paradigm to extend and enhance the traditional role of food banks in conversations and actions that address social justice issues.

KEYWORDS: Food banks; food rescue; neoliberal; socio-political; Dunedin; New Zealand

Food banks and, more latterly, food rescue organisations are an accepted part of the landscape. This article discuses their history internationally, nationally and, specifically in Dunedin/Otepoti and highlights the sociopolitical influences on their existence.

AOTEAROA NEW ZEALAND SOCIAL WORK 31(4), 72-83.

CORRESPONDENCE TO: Susan Wason

susan.wason@otago.ac.nz
Food rescue organisations generally concentrate on the rescue of perishable and prepared food that would normally go to landfills from places such as restaurants and supermarkets, and distribute it to community organisations for further redistribution to those in need (Poppendieck, 1998). Food banks tend to source food that would also usually go to waste from supermarkets and wholesalers, but also rely on donations from the community. In Dunedin/Ōtepoti, KiwiHarvest Dunedin/Ōtepoti's food rescue organisation, also supplies the food banks with food for distribution to those in need. Food banks have a stronger concentration on collecting non-perishable food but also deal in some perishable goods. Food banks 
are structured in one of two ways. The first is as a warehouse operated by a nonprofit organisation where food is collected and stored and then given to community social service groups to distribute to those in need, and the second way is as smallerscale more localised food banks where the social service organisations themselves collect, store and distribute the food (Riches, 1986). Food banks in Aotearoa New Zealand largely operate under the second model. Food rescue organisations generally fall under the first model and this is the case in Dunedin/Ōtepoti. There are other responses that have developed more recently to address the needs of those experiencing food poverty, such as Free Food organisations and community food pantries. This article focuses on food banks and food rescue organisations as, at the time the research was conducted, these were the two main sources of assistance available in Dunedin/ Otepoti to meet the food needs of those experiencing food poverty. For the purposes of this research, food poverty is considered to exist when a sector of society, despite the availability of food, is unable to access food to meet their needs through the usual social and economic means. This is usually due to insufficient income-commonly a consequence of neoliberal and reactionary social policy (Dowler \& O'Connor, 2011; Riches \& Silvasti, 2014).

\section{The beginnings of food banks}

Two of the most notable academics writing about food banks, Poppendieck (1998) and Riches (1986), concur that the world's first food bank was established in Phoenix, Arizona, United States of America (USA). Poppendieck (1998) dates 1967 as its inception. The food bank was set up as a charitable food resource for those who were struggling to meet their food needs at a time when the existing public social safety net was increasingly not meeting the needs of those it was designed to support (the sociopolitical context associated with the rise of food banks is discussed later in this article) (Riches, 2003). The food bank was also a mechanism to utilise the surplus of edible food that was being wasted (Riches, 2003). John van Hengel, a former businessman and Saint Vincent de Paul volunteer is credited with its establishment. He began gleaning fruit and vegetables and, as the venture grew, he sought assistance from Saint Mary's Church, Phoenix. In appreciation of the assistance from the church, John van Hengel named his food bank, The Saint Mary's Food Bank (Poppendieck, 1998; Riches, 1986). The scope of the food bank grew when John van Hengel was introduced to a woman who was feeding her children from a dumpster behind a local supermarket. John van Hengel visited the site of this dumpster and discovered a multitude of perishable dumped food, including vegetables, frozen food and bread. He also found non-perishable items at the back of the supermarket waiting to be dumped, including dented cans and leaking bags of sugar. He approached the manager of the supermarket and arranged for these items to be redirected to the food bank. Approaches were soon made to other supermarkets and the typical way of sourcing food for food banks from supermarkets was established (Poppendieck, 1998). This process remains the dominant way food banks source goods internationally and in Aotearoa New Zealand.

The term food bank is attributed to the woman who led John van Hengel to the dumpster. She is said to have drawn a cartoon depicting a bank in which food could be deposited by those with excess, and those in need could withdraw the excess (Poppendieck, 1998; Riches, 1986). In 1976 John van Hengel left Saint Mary's to establish Second Harvest, a national chain of food banks and then in 1983 he established what is now known as the Global FoodBanking Network, an association of food banks (Nelson, 2005).

Food banks became an international phenomenon. By the mid-1990s most OECD countries had food banks (McPherson, 2006). Hong Kong, Macao, Taiwan and China emerged into food banking this century (Riches, 2011). The first Aotearoa 
New Zealand food bank was thought to have been established in Auckland in 1980 (Crack, 2001; Mackay, 1995; McPherson, 2006; Uttley, 1997; Whale, 1993).

By 1994 there were an estimated 365 food banks in Aotearoa New Zealand and a third of these were located in the Auckland area (Mackay, 1995). The food banks were predominantly attached to voluntary organisations where other social services were also provided (Whale, 1993). About $95 \%$ of the food banks were church initiated (Whale, 1993). Attempts by those researching food banks to establish more accurate numbers proved difficult and one researcher concluded that the lack of a national database of food banks contributed to this (Mackay, 1995). This helps to explain why the literature lacks specificity about the emergence of these early food banks. This reflects comments in the international and Aotearoa New Zealand literature relating to the lack of baseline and historical data to determine the number of food banks (Crack, 2001; Poppendieck, 1998). The lack of data is significant as it impacts on the ability to research the development of food banks and to tell the particular story of each one. The research from this 2017 study concluded that the localised food banks that developed in Dunedin/Ōtepoti meant that they developed in an ad hoc manner and there was little written about the historical specifics of their development (Wason, 2017). The emergence of food banks in Dunedin/Ōtepoti is discussed later in this article.

\section{Food rescue organisations emerge}

While food banks continued to grow both internationally and nationally, another form of collecting food to be redistributed for those experiencing food poverty emerged. This new model focused particularly on perishable food that would normally be wasted. The sourcing of this food was complementary to, rather than competitive with, food banks, although inevitably some overlap developed. City Harvest in New York which started in 1982, is credited with being the world's first food rescue organisation (City Harvest, n.d.; Poppendieck, 1998). As occurred with food banks, these food rescue organisations in the USA formed a network and, by the end of the 1980s, the network was well established (Poppendieck, 1998). After the establishment of City Harvest, food rescue organisations began to appear in other countries, such as Canada in 1985, the United Kingdom in 1994 (Poppendieck, 1998), and Australia in 2001 (FareShare, n.d.).

The first Aotearoa New Zealand food rescue organisation was Kaibosh established in Wellington in 2008 (Kaibosh, n.d.; Macfie, 2016). Further food rescue organisations soon followed and they now operate across the country. FoodShare, now known as KiwiHarvest was established in 2012 and is Dunedin/Ōtepoti's food rescue organisation (KiwiHarvest, n.d.).

\section{The socio-political context}

There is general agreement in the international literature including Cloke, May, and Williams (2016), Poppendieck (1994, 1998, 2014) and Riches (1986, 1997, $2003,2011)$, that the impetus for the rise of food banks was a reaction to the increased needs caused by the introduction of neoliberal policies and significant reductions in welfare-state-type provisions. There is also agreement between Poppendieck (1994, 2014) and Riches (1997) and others that these reductions in welfare provisions were usually accompanied by rising unemployment and deteriorating economic conditions and that this, along with neoliberal structural reforms, resulted in increased poverty and a subsequent need for many of those to seek food assistance. Most of the Aotearoa New Zealand literature and commentary also concurs with this premise (Crack, 2001; Leslie, 1996; Mackay, 1995; McPherson, 2006; O’Brien, 2014; Olds, 1991; Whale, 1993; Wynd, 2005). In Aotearoa New Zealand, the background to these changing socio-political conditions began with significant economic and social 
restructuring in 1984 by the fourth Labourled government (Kelsey, 1995). This restructuring was taken to a deeper level by the 1990 National government who, shortly after its election, announced cuts to most social security benefits. These cuts, the impact of the Employment Contracts Act 1991, the implementation of market rentals for state housing, increasing unemployment and increased expenses for families meant that those in need were increasingly turning to food banks (Carlyon \& Morrow, 2013; Crack, 2001; Leslie, 1996; Mackay, 1995; McPherson, 2006; Olds, 1991; Wynd, 2005). Faced with the effects of this politically created crisis, food banks became a community response to need (McPherson, 2006; Riches, 2003).

In contrast to the viewpoint previously described, McLoughlin (1994) contended that the growth in food banks in Aotearoa New Zealand was more about the existence of food banks becoming known and that most of those in receipt of benefits managed on reduced incomes. This view, that the growth in food banks was related to publicity rather than the reduction in benefit levels, was an isolated one in the commentary, but may well have reflected some societal views at the time.

The increase in food bank usage as a result of the 1991 benefit cuts in this country is widely acknowledged in the literature (including Barwick \& McGurk, 1994; Crack, 2001; Leslie, 1996; McPherson, 2006; Olds, 1991). It also appears that the Department of Social Welfare, the government department charged with administering social security benefits, also began to encourage its clients to access food banks. The research undertaken by Olds (1991) and by Barwick and McGurk (1994) confirmed that the New Zealand Income Support Service staff (a branch of the Department of Social Welfare, now referred to as Work and Income) was a referrer to food banks. This was particularly significant, firstly as the government was denying the practice and questioning the need for food banks and, secondly, because it could be interpreted as confirming that benefit levels (reduced as a result of the 1991 cuts) were inadequate to meet essential needs (Barwick \& McGurk, 1994; Olds, 1991). Work and Income as a referrer to food banks was also confirmed in McPherson's 2006 research and in a small Dunedin/Ōtepoti study (Houghton, Nelson, Niblock, Goodyear \& Anglican Methodist Family Care Centre, 1998). As well as helping to normalise and institutionalise food banks, it also served to legitimise them as a means to supplement state income maintenance assistance.

Apart from the views of McLoughlin (1994) the literature reviewed for this article concurs that food banks emerged at a time of economic and social hardship largely brought about by the socio-political changes begun by the fourth Labour-led government and continued with an increased vigour by the 1990 National government. The reforms outlined led to a society with increasing inequality where food banks became an increasingly utilised mechanism for those in need to seek food they were unable to purchase (Crack, 2001; Kelsey, 1995; Leslie, 1996; Mackay, 1995; McPherson, 2006; O'Brien, 2014; Olds, 1991; Whale, 1993; Wynd, 2005). The change in the philosophy of the state from a society where benefit levels were based on the premise of the ability to fully participate in society to a neoliberal society with a modest safety net meant that Aotearoa New Zealand moved to the state as a safety net and individual responsibility. This was reminiscent of society prior to the Welfare State which began with the election of the Labour government in 1935 (Carlyon \& Morrow, 2013; Roper, 2008; O’Brien \& Wilkes, 1993, as cited in Leslie, 1996; Shipley, Upton, Smith, \& Luxton, 1991; New Zealand Government, 1972; Thomson, 1998).

Food banks were a response by the voluntary and community sector to meet the food needs of a sector of society increasingly impacted by these socio-political changes. As discussed earlier, the food banks were established by voluntary organisations with most being attached to, or supported by, 
churches (Whale, 1993). Since the beginnings of colonisation in Aotearoa New Zealand, churches had played a dominant role in assisting those experiencing poverty, particularly food poverty (Thomson, 1998). This role had decreased during the period of the Welfare State due to the increased availability of income assistance and the ability of those on benefits to purchase food (Carolyn \& Morrow, 2013; Olssen, 1984). The role of the church and voluntary organisations in supplying food re-emerged from the mid-1980s and particularly after the 1991 benefit cuts as neoliberalism took hold (Carlyon \& Morrow, 2013; McPherson, 2006). Food banks as a response soon became permanent fixtures and were normalised as many stakeholders became reliant on them including food bank users, government, volunteers, businesses and the community (Crack, 2001; Dowler, 2014; Leslie, 1996; Mackay, 1995; McPherson, 2006; O'Brien, 2014; Olds, 1991; Poppendieck, 1998; Riches, 1986; Tarasuk \& Eakin, 2005; Whale, 1993).

A response to the increased demand placed on food banks was the use of publicity and the media to encourage donations. The seeking of publicity for donation purposes appeared to be initiated by both the media and the food banks (Wason, 2017). The use of the media in this way is criticised by some in the literature as portraying food banks as appropriate mechanisms to address food poverty (including Poppendieck, 1994, 1998; Riches, 2003; Riches \& Tarasuk, 2014) and "...as a matter of charity not politics" (Riches, 2003, p. 95). This usage is seen as reinforcing the provision of food as a gift and not a right and can result in the perception of food banks as acceptable mechanisms to address food poverty (Riches \& Silvasti, 2014). It also reinforces what Poppendieck (1998) refers to as the "halo effect" where a positive psychological "feel good" benefit is received from the public acknowledgement of giving. While giving to food banks is admirable, it also serves to reinforce charity as an appropriate response and to depoliticise food poverty (Poppendieck, 1998). The trajectory for food banks is therefore complicated as they work to provide food for those impacted by political manoeuvres.

In the beginning, most Aotearoa

New Zealand food banks engaged in social action to highlight the social justice issues associated with the rise of food banks (Milner, 2004; Wason, 2017; McPherson, 2006; Wynd, 2005). Some actions were nationally organised, such as an attempt at a day of protest but most were locally driven (O'Brien, 2014). Leslie's (1996) Palmerston North research concluded that not all the food banks involved in her study were actively working to alleviate poverty. While all were meeting the immediate needs of providing food she called for them to also operate from an empowerment theoretical basis, "...by employing strategies such as advocacy, political lobbying, and public education..." (p. 146). Wakefield, Fleming, Klassen, and Skinner (2012), in their Canadian research, also discuss the opportunities and importance for organisations responding to food poverty to engage in this type of discourse and the openings for collaboration. They also acknowledge the difficulties of this approach, but emphasise the essentiality of such an approach to help facilitate structural and social change. Much of the literature (including Booth \& Whelan, 2014; Crack, 2001; Dey \& Humphries, 2015; LambieMumford, 2013; Poppendieck, 1998; Riches, 2011) suggests food banks, by their very existence, can be viewed as supporting the policies that created the need for them, but that they also play an important role in meeting the needs of those requiring food. Dey and Humphries (2015) describe this as the paradox in which food banks operate. Food banks' charitable role versus their social action role is complex. They operate in a world with competing expectations and some of those expectations, such as social action may be more than they have the resources to become involved in, or they may not see social action as one of their roles. A reduced focus on social action was evident in the findings of the research for this thesis. This was particularly noticeable 
in the newspaper reporting where, from about 2005, the social action theme almost disappeared and a concentration on requests for donations and acknowledgements became dominant (Wason, 2017).

An associated issue with the complex political space in which food banks function is the process of accessing them. A considerable amount of the literature reviewed, including the Aotearoa New Zealand literature of Leslie (1996), McPherson (2006) and Milner (2004) discussed the processes that food bank organisations established to limit access, assess a person's need, establish whether their circumstances required further exploration and whether they would benefit from additional services. Leslie (1996) comments on how these processes can serve to further stigmatise and reinforce the notion of individual failing and create barriers for those already marginalised. Restricted access and assessment suggests blame and reintroduces concepts of deserving and undeserving poor that have been traditionally associated with charitable giving since biblical times (Kahl, 2005; Tennant, 1989; Thomson, 1998). The gathering of assessment information can be useful particularly to highlight social justice issues such as poverty (Milner, 2004; NZCCSS, 2005), however, as Dey and Humphries (2015) and Leslie (1996) amongst others note, access criteria and assessment processes can be viewed as organisations focusing on issues as individual failing and reinforcing neoliberal ideologies.

None of the literature reviewed saw the rise of food banks as being caused by a shortage of food (see Riches \& Silvasti, 2014; Silvasti, 2015); but rather the issue is the reduction in a sector of society's purchasing power in a climate of plentiful food. The rise of food rescue organisations confirms this view. Lorenz (2012), in his research on food rescue organisations, argued that the generation of surplus is seen as a solution to addressing food waste. He further commented that “...the perception of surplus as a resource stands in the way of criticising the generation of surplus..." (p. 392). This suggests that, while food rescue organisations have an important environmental focus and reduce food waste, their existence depends on the production of surplus food making it difficult to have a political position opposing surplus production. Lindberg, Lawrence, Gold, and Friel (2014), in their Australian research, noted the improved nutritional benefits that food rescue organisations add to the emergency food arena, but also questioned whether it was "...inadvertently making 'the problem' worse?" (p. 1487). Mirosa, Mainvil, Horne, and Mangan-Walker (2016) note the nutritional benefits and the social value of food rescue organisations. This suggests that food rescue organisations can be viewed as contributing to the availability of increased fresh food and reducing waste, but complexities and contradictions exist for them and the environmental contradictions are significant.

\section{The Dunedin/Ōtepoti story}

Food banks in Dunedin/Ōtepoti, like the rest of the country, were a response to the effects of the radical political changes begun in 1984 and solidified in 1990 (Wason, 2017).

Crack (2001), Milner (2004), Parnell (2005) and Shannon (2009) are the researchers looking specifically at Dunedin/Ōtepoti in relation to food banks. Houghton et al. (1998) undertook a small Dunedin/Ōtepoti study looking at what life on a benefit was like from the perspective of the recipients. This study discussed food banks briefly. A further resource providing data on Dunedin/Ōtepoti is the New Zealand Council of Christian Social Services (NZCCSS, 2005, 2008) Poverty Indicator Project. The project involved seven food banks across the country participating in a four-year study with the aims of gathering information about the issues of poverty as experienced by food bank users and creating greater public and government awareness. Presbyterian Support Otago was involved in this project. Another useful resource is the Dunedin/Ōtepoti newsprint media. 
A review of newsprint articles from 1991 to 2017 formed part of the research for the thesis on which this article is based. These sources provide rich data and a summary of the findings from these sources is discussed in the following sections.

\section{The development of food banks}

Despite extensive searching, there is no concrete evidence of the exact date food banks emerged in Dunedin/Ōtepoti; however, it appears that, by 1992, five food banks were operating-Presbyterian Support, St Vincent de Paul, Anglican Methodist Family Care, the Salvation Army and the Mosgiel Community Food Bank-and it seems these organisations had formalised their services between 1991 and 1993 (Crack, 2001; “Food bank drying up," 1991; Milner, 2004; Tipa, 1993; Wason, 2017). Crack (2001), who undertook the first study of Dunedin/Ōtepoti food banks, adds Advisory and Support Centre to the list of food banks although, at the time of his research, it had recently closed and there is very little information or reference to it in other information, such as newspaper articles.

The five organisations offering a food bank service in Dunedin/Ōtepoti were Christianbased and had a history of providing social assistance to those in need. It would seem that these Christian-based food bank organisations were involved in some small-scale food distribution prior to 1991 (Olssen, 1984; Rae \& PSSA, 1981) but they only became part of a formalised system from about 1991. Catherine Goodyear, the Director of Anglican Methodist Family Care is quoted in a newspaper article as saying, "We had never used the term foodbank before 1991" (Ramsay, 1998, p. 9). The Mosgiel Community Food Bank was the only newly created entity, however, it was created through the cooperation of eight Taieri churches (Mosgiel is the biggest town in the Taieri area) ("Caring in the community," 1992) and, as such, it too had a history of churches meeting the needs of the poor.
The Otago University Student Association opened a food bank in 2004 (McKinlay, 2004). Anglican Family Care (formerly Anglican Methodist Family Care) closed their food bank in 2016.

\section{Reasons for use}

The Poverty Indicator Project found that frequent reasons for accessing food banks were housing costs, electricity, gas and unexpected expenses (NZCCSS 2005, 2008). This was also a finding from the review of the newsprint media. The cost of utilities such as power, electricity, gas, rent and unexpected expenses (such as car repairs, replacing or repairing an appliance, dental, medical costs) and school costs emerged as recurring reasons cited by the food banks throughout many of the newspaper articles ("Demand grows for food parcels," 1992; "Foodbank demand doubles," 2014; Harris, 1994, 1996; McKnight, 2011; Rickerby, 1999; Smith, 2004; Stewart, 2002). This suggests that meeting routine costs and unexpected expenses were a continuing issue for those experiencing food poverty and food banks were increasingly used when income was insufficient to meet these needs.

\section{Demand}

An aim of the Poverty Indicator Project was to produce consistent data by the food banks collecting their information in the same manner (NZCCSS, 2005). Despite this commitment, consistent statistics proved difficult because of, for example, differences in the definitions of what constitutes a food parcel and food bank policies (McPherson, 2006).

One of the most comprehensive newsprint articles (Tipa, 1993) reported on the situation from 1991 until July 1993. Food banks reported seeing a three-figure increase in demand and two had seen demand rise between 500 and $730 \%$. This article further reports that all the food banks saw a direct relationship between the 1991 benefit cuts and the increase in demand for food parcels. 
An Otago Daily Times article (Goodger, 1998a) quotes Catherine Goodyear, the Director of Anglican Methodist Family Care, as saying it had 360 requests for food parcels in 1989 and 3,000 from 1994. Presbyterian Support was quoted as supplying 10 parcels a week "years" ago and 80 a week in 1998. In September 2016, Presbyterian Support estimated it was giving out between 100 and 120 parcels per week (or between 5,200 and 6,240 per year) and the Salvation Army 80 parcels per week or 4,160 per annum. Saint Vincent de Paul (SVDP) estimated they were giving out 60 parcels per week (or 3,120 per annum) (Yeoman, 2016). It is inappropriate to compare these figures as it is highly likely that food banks collected their statistics in different ways. However, it seems fair to conclude that the demand for food bank services remains, but that the rate of demand is not at the exponential rate initially experienced.

The Director of Presbyterian Support Otago at the time of the Poverty Indicator Project used the newsprint media as a mechanism to report on trends emerging. This reporting also served a social action role and aimed to create greater awareness of the issues facing food banks (Milner, 2004). One of the significant findings across the country, and in Dunedin/Ōtepoti, was that most food bank users were female (NZCCSS, 2005). Although significant, it is not surprising, as the 1991 benefit cuts and the abolition of the Family Benefit negatively impacted women and those with children, in particular.

All of the food banks reported they believed they were dealing with genuine cases of need as those who had started coming to them had coped well prior to the benefit cuts. This suggests that the benefit reforms, designed to provide a "...safety net..." for "...a modest standard of living,..." (Shipley et al., 1991, p. 4) providing "...sufficient assistance to maintain individuals and families in the daily essentials of food, clothing, power and housing at a decent level" (Shipley et al., 1991, p. 13) were falling short.
While this article has concentrated on the impact on those receiving benefits, nonbeneficiaries also accessed food banks. Many of these recipients were the working poor, those made redundant and a small number of Dunedin/Ōtepoti's senior citizens (Goodger, 1998b; Harwood, 2009; Ramsay, 1998; Rickerby, 1999).

\section{Acceptance of food banks}

The normalisation of food banks discussed earlier led to concern about food banks becoming institutionalised. Annette Garrett, from the Dunedin Salvation Army, was quoted by Harris (1996) as being concerned: "My biggest concern is that we've accepted food banks as an institution..." (p. 4), and the Reverend Ian Robertson, from Presbyterian Support, was quoted by Howe (1996) as seeing it as "...unacceptable for food banks-a solution to a crisis-to be a permanent part of society and politicians needed to give priority to alleviating the need for food banks" (p. 14). Clearly, the organisations in Dunedin/Ōtepoti providing food bank services were aware that, in providing food, they were meeting the immediate needs of those requiring assistance, but that there was also action needed at societal and political levels.

\section{Social action}

As discussed earlier, social action was a significant activity for many food banks. An example of this was the 1996 National Action on Poverty Week. This was a week when there was a call from some food banks for all food banks to close for a day in a protest move. This idea did not come to fruition across the country as many food banks were concerned about the vulnerability of their clients (Heenan, 1996; Rooney, 1996). The Dunedin/Ōtepoti food banks chose not to close, instead marking the day with a rally in the Octagon. The public was invited and "[s]ongs were sung and speeches on the shame and problems of poverty were delivered by representatives from political parties, non-governmental social 
organisations and churches" (Howe, 1996, p. 14). As a visual representation of the extent of poverty in Dunedin/Ōtepoti, 1,200 balloons representing the 12,000 food parcels given out in the past year were provided. Members of the public were invited to burst the balloons (Heenan, 1996). There were only a few further articles focused on social justice, such as one on Presbyterian Support seeking funding to staff an advocacy-type position. The Director of the organisation was quoted, by Rudd (2001), as saying:

There seems to be an acceptance that a group in the community will never fully participate because of their financial circumstances. We find that distasteful. (p. 20)

This suggests that the Dunedin/Ōtepoti food banks engaged in social justice activities which helped ensure a structural focus rather than attempting solely to meet immediate food poverty needs.

\section{Encouraging donations}

The social action evident in the newsprint reporting diminishes about 2005, which coincides with the end of Poverty Indicator Project. The focus shifts to the plight of food bank stocks and the efforts of the community including the Dunedin City Council, schools and businesses to support the food banks with article titles such as "Fruitful day produces bounty for food bank" (Manins, 2014), "Generous Mosgiel" (Beaumont, 2010) and "Foodbanks' resources stretched" (Constantine, 2011). There are many articles detailing the desperate situation for food banks and the need for community assistance to fill their shelves. Whether these articles resulted from the newspapers approaching the food banks or the food banks approaching them is unclear. It is likely that it was a combination of both. Article headlines such as "Cupboards bare at food banks" (Hepburn, 2008), "FW food bank in crisis" (McCorkindale, 2011) are two of those designed to elicit a response from the public to increase food bank stocks.
This change in reporting and emphasis perhaps reflects the growing acceptance and normalisation of food banks in the Dunedin/ Ōtepoti community.

Another form of encouraging donations from the community are the two annual Christmas food drives. These involve emergency services and volunteers driving through the streets on a December evening collecting non-perishable food from households donating to the food banks. The drive started in the Mosgiel area in 1992 and spread to Dunedin/Ōtepoti the following year (Harvey, 2008). According to Harvey (2008), the idea was generated by a Mosgiel Police Sergeant, Maurice Phiskie. Radio, emergency services and the Taieri Lions initially supported this venture and it was successfully run and has continued since. Reporting regularly occurs each year, both before and after this event, in the Otago Daily Times and in the local newspapers, presumably to publicise and increase the level of giving.

\section{Food rescue comes to Dunedin/Ōtepoti}

KiwiHarvest Dunedin/Ōtepoti's food rescue organisation, began operating in Dunedin/Ōtepoti in 2012. Established as a social enterprise with a specific focus of operating as a business and reducing food poverty in the community, it quickly became successful in organising Dunedin/ Ōtepoti businesses to donate their excess or food waste (KiwiHarvest, n.d.; Mirosa et al., 2016). Success is measured in terms of food redistributed and environmental savings. In their first month of operation, their statistics show they distributed the equivalent of 1,000 meals and by 2015 they were distributing 30,000 per month (Mirosa et al., 2016). This suggests that KiwiHarvest's presence in the Dunedin/Ōtepoti emergency food provision sector is increasingly significant.

Mirosa et al.'s (2016) research focused on the added social value of KiwiHarvest for both stakeholders and the community. KiwiHarvest's entry into the emergency 
food provision arena was well organised and appears, from information on their website, and the study by Mirosa et al. (2016), to have significantly increased the availability of perishable food to be redistributed to those in need in Dunedin/Ōtepoti. Mirosa et al. (2016) view KiwiHarvest as apolitical and see KiwiHarvest as being there in the short term, "...whilst longer-term solutions to the problems of insecurity and waste are sought" (p. 3055). KiwiHarvest is not engaged in social action. KiwiHarvest may not have an interest in politics, but they do have a strong environmental focus and one of their success measures is the environmental savings from rescuing food. As with food banks, their existence can be viewed as inadvertently contributing to the normalisation and institutionalisation (see Poppendieck, 1994, 1998; Riches, 2003) of current Aotearoa New Zealand responses to food poverty. While their existence results in a greater supply and availability of food to those in need it remains a charitable response.

\section{Conclusion}

This article has provided a history of the development of food banks and food rescue organisations internationally, nationally and specifically in Dunedin/Ōtepoti. It has also briefly discussed the socio-political context which significantly contributed to the ad hoc development of food banks and the purposeful development of food rescue organisations. Food banks and food rescue organisations perform an important role in helping to meet the needs of those experiencing food poverty and also in reducing the amount of food waste. They also, however, are a symptom of a society that has accepted a charitable response to food poverty as normal. The world in which food banks and food rescue organisations operate is a complex and contradictory one as they meet the needs of those seeking food but also in doing this, as much of the research on which this article is based concludes, they inadvertently support the system that creates the need for their existence. This review of the literature will hopefully encourage the reader to further explore the role of food banks and food rescue organisations in society.

\section{References}

Barwick, H., \& McGurk, T. (1994). Passing the buck New Zealand Income Support Service procedures for assessing applications for emergency assistance: the problem of Department of Social Welfare referrals to foodbanks: A report. Wellington, New Zealand: The Downtown Ministry.

Beaumont, M. (2010, October 26). Generous Mosgiel. Taieri Herald, p. 3.

Booth, S., \& Whelan, J. (2014). Hungry for change: The food banking industry in Australia. British Food Journal, 116(9), 1392-1404. https://doi.org/10.1108/BFJ-01-2014-0037

Caring in the community. (1992, July 21). Taieri Herald, p. 1.

Carlyon, J., \& Morrow, D. (2013). Changing times: New Zealand since 1945. Auckland, New Zealand: University Press.

City Harvest. (n.d.). About us. Retrieved from https://www. cityharvest.org/about-us/our-story/

Cloke, P., May, J., \& Williams, A. (2016). The geographies of food banks in the meantime. Progress in Human Geography, 41(6), 1-24. Retrieved from http://journals. sagepub.com/doi/pdf/10.1177/0309132516655881

Constantine, E. (2011, March, 17). Foodbanks' resources stretched. Otago Daily Times, p. 2.

Crack, S. (2001). The face of poverty: Foodbank location and use in Dunedin (Unpublished Bachelor of Arts [hons] dissertation). University of Otago Dunedin, New Zealand.

Demand grows for food parcels. (1992, August 25). Taieri Herald, p. 1.

Dey, K., \& Humphries, M. (2015). Recounting food banking: A paradox of counterproductive growth. Third Sector Review, 21(2), 129-147.

Dowler, E. (2014). Food banks and food justice in "Austerity Britain." In G. Riches \& T. Silvasti (Eds.), First world hunger revisited (2nd ed., pp 160-175). Basingstoke, England: Palgrave-Macmillan.

Dowler, E., \& O'Connor, D. (2012). Rights based approaches to addressing food poverty and food insecurity in Ireland and UK. Social Science and Medicine, 74(1), 44-51. https://doi.org/10.1016/j.socscimed.2011.08.036

FareShare. (n.d.). History. Retrieved from http://www. fareshare.net.au/history/

Foodbank demand doubles. (2014, June 5). Otago Daily Times, p. 26.

Food bank drying up. (1991, December 10). Taieri Herald, p. 3.

Goodger, G. (1998a, August 11). Foodbanks struggle with demand. Otago Daily Times, p. 4.

Goodger, G. (1998b, November 28). Foodbanks facing heavy demand. Otago Daily Times, p. 3.

Harris, L. (1994, March 19). More forced to use food banks. Otago Daily Times, p. 5.

Harris, L. (1996, August 7). Foodbanks have "never been so busy." Otago Daily Times, p. 4.

Harvey, S. (2008, December 11). Stepping down after 12 years. Otago Daily Times, p. 8. 
Harwood, B. (2009, October 29). Supportive community helps shelves stay full. The Star, p. 21.

Heenan, C. (1996, September 26). Foodbanks will mark poverty day. Otago Daily Times, p. 22.

Hepburn, S. (2008, June 17). Cupboards bare at food banks. Otago Daily Times, p. 5.

Houghton, R. M., Nelson, D., Niblock, S., Goodyear, C., \& Anglican Methodist Family Care Centre. (1998). Our lives in their hands: Looking at life on a benefit: a report based on a study on the views of beneficiaries living in Dunedin. Dunedin, New Zealand: Anglican Methodist Family Care Centre.

Howe, F. (1996, October 4). Rally focuses attention on need for food banks. Otago Daily Times, p. 14.

Kahl, S. (2005). The religious roots of modern poverty policy: Catholic, Lutheran, and Reformed Protestant traditions compared. European Journal of Sociology, 46(1), 91-126. http://dx.doi.org/10.1017/ s0003975605000044

Kaibosh. (n.d.). About us. Retrieved from http://www.kaibosh org.nz/about-us/

Kelsey, J. (1995). The New Zealand experiment: A world model for structural adjustment? Auckland, New Zealand: Auckland University Press.

KiwiHarvest. (n.d.). About. Retrieved from http://kiwiharvest. org.nz/about/

Lambie-Mumford, H. (2013). "Every town should have one": Emergency food banking in the UK. Journal of Social Policy, 42(1), 73-89. doi:10.1017/S004727941200075X

Leslie, H. (1996). Banking on foodbanks for poverty alleviation? A critical appraisal of Palmerston North foodbanks' development practices (Unpublished master's thesis). Massey University, Palmerston North, New Zealand. Retrieved from http://hdl.handle. net/10179/5861

Lindberg, R., Lawrence, M., Gold, L., \& Friel, S. (2014). Food rescue: An Australian example. British Food Journal, 116(9), 1478-1489. https://doi.org/10.1108/BFJ-012014-0053

Lorenz, S. (2012). Socio-ecological consequences of charitable food assistance in the affluent society: The German Tafel. International Journal of Sociology and Social Policy, 32(7/8), 386-400. https://doi. org/10.1108/01443331211249011

Macfie, R. (2016, July 1). A growing army of New Zealanders is waging a war on waste. New Zealand Listener. Retrieved from http://www.noted.co.nz/currently/socialissues/a-growing-army-of-new-zealanders- is-waging-awar-on-waste/

Mackay, R. (1995). Foodbank demand and supplementary assistance programmes: A research and policy case study. Social Policy Journal of New Zealand, 5, 129-141.

Manins, R. (2014, February 5). Fruitful day produces bounty for food bank. Otago Daily Times, p. 29

McCorkindale, W. (2011, August 24). FW foodbank in crisis. D Scene, p. 8.

McKinlay, T. (2004, March 30). Student association establishes foodbank. Otago Daily Times, p. 5

McKnight, T. (2011, June 11). Octacan brings in 6000 items. Otago Daily Times, p. 5.
McLoughlin, D. (1994). Foodbank fever. North and South: New Zealand's lifestyle magazine. Nov, 104, 60-63. Auckland, New Zealand: Fith Publishing.

McPherson, K. (2006). Food insecurity and the food bank industry: Political, individual and environmental factors contributing to food bank use in Christchurch (Unpublished master's thesis). University of Canterbury, Christchurch, New Zealand). Retrieved from https://ir.canterbury.ac.nz/bitstream/handle/10092/1351/ thesis_fulltext.pdf?sequence $=1$ \&isAllowed $=y$

Milner, V. (2004). A model for the new frontier of social work: Using respect, empathy, curiosity and time. Social Work Review, 16(3), 38-43. Retrieved from http://anzasw.nz/ wp-content/uploads/Social-Work-Review-16-Spring-04Article- Milner.pdf

Mirosa, M., Mainvil, L., Horne, H., \& Mangan-Walker, E. (2016). The social value of rescuing food, nourishing communities. British Food Journal, 118(12), 3044-3058. https://doi.org/10.1108/BFJ-04-2016-0149

Nelson, V. (2005, October 9). John van Hengel, 83; Set up $1^{\text {st }}$ food bank. Los Angeles Times. Retrieved from http://articles.latimes.com/2005/oct/09/local/me-vanhengel9

New Zealand Council of Christian Social Services (NZCCSS). (2005). Forgotten poverty? Poverty indicator project: Foodbank study final report. Wellington, New Zealand: Author.

New Zealand Council of Christian Social Services (NZCCSS). (2008). Poverty indicator project update: A snapshot comparative analysis of foodbank use December quarter 2004 and December 2007. Wellington, New Zealand: Author.

New Zealand Government. (1972). Social security in New Zealand: Report of the Royal Commission of Inquiry. Wellington, New Zealand: Government Printer.

O'Brien, M. (2014). Privatizing the right to food: Aotearoa/ New Zealand. In G. Riches \& T. Silvasti (Eds.), First world hunger revisited: Food charity or the right to food? (pp. 102-116). Basingstoke, England: Palgrave Macmillan.

Olds, B. (1991). Food for thought: Research on foodbanks. Auckland, New Zealand: Methodist Mission Aotearoa.

Olssen, E. (1984). A history of Otago. Dunedin, New Zealand: J. Mclndoe.

Parnell, W. (2005). Food security in New Zealand (Unpublished doctoral thesis). University of Otago, Dunedin, New Zealand

Poppendieck, J. (1994). Dilemmas of emergency food: A guide for the perplexed. Agriculture and Human Values, 11(4), 69-76. doi:10.1007/BF01530418

Poppendieck, J. (1998). Sweet charity? Emergency food and the end of entitlement. New York, NY: Viking.

Poppendieck, J. (2014). Food assistance, hunger and the end of welfare in the USA. In G. Riches \& T. Silvasti (Eds.), First world hunger revisited: Food charity or the right to food? (pp. 176-190). Basingstoke, England: Palgrave Macmillan.

Rae, S., \& Presbyterian Social Service Association (Dunedin). (1981). From relief to social service: A history of the Presbyterian social service association, Otago, 1906-1981. Dunedin, New Zealand: The Association.

Ramsay, C. (1998, June 29). Welfare cuts to deal with soaring costs. Otago Daily Times, p. 9. 
Riches, G. (1986). Food banks and the welfare crisis Ontario, Canada: Love Printing Services.

Riches, G. (1997). Hunger and the welfare state: Comparative perspectives. In G. Riches (Ed.), First world hunger (pp. 1-13). Basingstoke, England: Palgrave Macmillan.

Riches, G. (2003). Food banks and food security: Welfare reform, human rights and social policy. Lessons from Canada. In E. Dowler \& C. Jones Finer (Eds.), The welfare of food: Rights and responsibilities in a changing world (pp. 91-105). Oxford, England: Blackwell.

Riches, G. (2011). Thinking and acting outside the charitable food box: Hunger and the right to food in rich societies. Development in Practice, 21(4-5), 768-774. http://dx.doi. org/10.1080/09614524.2011.561295

Riches, G., \& Silvasti, T. (2014). Hunger in the rich world: Food aid and right to food perspectives. In G. Riches, \& T. Silvasti (Eds.), First world hunger revisited ( $2{ }^{\text {nd }}$ ed., pp. 1-14). Basingstoke, England: Palgrave-Macmillan.

Riches, G., \& Tarasuk, V. (2014). Canada: Thirty years of food charity and public policy neglect. In G. Riches \& T. Silvasti (Eds.), First world hunger revisited ( $2^{\text {nd }}$ ed., pp. 42-56). Basingstoke, England: Palgrave-Macmillan.

Rickerby, A. (1999, October 11). Food bank use expected to rise. Otago Daily Times, p. 5.

Rooney, E. (1996, September 22). Food banks to close in protest move. Sunday Star Times, p. A1.

Roper, B. (2008). The welfare state: Origins, development, crisis and redesign. In N. Lunt, M. O'Brien, \& and R. Stephens (Eds.), New Zealand, new welfare ( $1^{\text {st }}$ ed., pp. 10-18). Melbourne, Australia: Cengage Learning Australia.

Rudd, A. (2001, April 30). Aid agency needs donors to improve foodbank service. Otago Daily Times, p. 20.

Shannon, P. (2009). The exclusion process and hardship prevention -A report for Christian helping agencies group/Dunedin city council. Dunedin: Department of Social Work and Community Development, University of Otago, New Zealand.

Shipley, J., Upton, S., Smith, L., \& Luxton, J. (1991). Social assistance: Welfare that works: A statement of government policy on social assistance. Wellington, New Zealand: New Zealand Government.

Silvasti, T. (2015). Food aid-normalising the abnormal in Finland. Social Policy and Society, 14(3), 471-482.

Smith, J. (2004, July 9). Winter keeping foodbanks busy. Otago Daily Times, p. 4.

Stewart, L. (2002, October 17). Foodbanks struggle to meet demand. Otago Daily Times, p. 3.

Tarasuk, V., \& Eakin, J. M. (2005). Food assistance through "surplus" food: Insights from an ethnographic study of food bank work. Agriculture and Human Values, 22(2), 177-186.

Tennant, M. (1989). Paupers \& providers: Charitable aid in New Zealand. Wellington, New Zealand: Allen \& Unwin New Zealand and Historical Branch, Dept. of Internal Affairs.

Thomson, D. (1998). A world without welfare: New Zealand's colonial experiment. Auckland, New Zealand: Auckland University Press.

Tipa, R. (1993, July 10). Brighter outlook but no sign of benefits. Otago Daily Times, p. 19.
Uttley, S. (1997). Hunger in New Zealand: A question of rights? In G. Riches. (Ed.), First world hunger: Food security and welfare politics (pp. 78-107). Basingstoke, England: Palgrave Macmillan.

Wakefield, S., Fleming, J., Klassen, C., \& Skinner, A. (2012). Sweet charity, revisited: Organizational responses to food insecurity in Hamilton and Toronto, Canada. Critical Social Policy, 33(3), 427-450. Retrieved from http://journals.sagepub.com/doi/ pdf/10.1177/0261018312458487

Wason, S. (2017). Saints or Communists? The story of Dunedin/Ötepoti food banks and FoodShare (Unpublished master's thesis). University of Otago, Dunedin, New Zealand.

Whale, A. (1993). Voluntary welfare provision in a landscape of change: The emergence of foodbanks in Auckland (Unpublished master's thesis). University of Auckland, Auckland, New Zealand.

Wynd, D. (2005). Hard to swallow: Foodbank use in New Zealand. Auckland: Child Poverty Action Group. Retrieved from: http://www.cpag.org.nz/assets/ Publications/HTS.pdf

Yeoman, G. (2016, September 22). Foodbank stigma concerns agencies. The Star, p. 12. 